\title{
RESPONSE OF SPECKLED SPUR-FLOWER TO SALINITY STRESS AND SALICYLIC ACID TREATMENT
}

\author{
Piotr Salachna' ${ }^{1}$ Rafał Piechocki' , Agnieszka Zawadzińska' ${ }^{1}$, Andżelika Wośkowiak' \\ 1 Department of Horticulture, Faculty of Environmental, Management and Agriculture, West Pomeranian \\ University of Technology, Papieża Pawła VI 3, 71-459 Szczecin, Poland, e-mail: piotr.salachna@zut.edu.pl; \\ rafal.piechocki@zut.edu.pl; agnieszka.zawadzinska@zut.edu.pl; andzelika.wosko-wiak@zut.edu.pl
}

Received: 2015.08 .07 Accepted: 2015.10 .06 Published: 2015.11.10

\begin{abstract}
One of the limitations to using ornamental plants in green areas is too high salinity and alkalization of the soil. The adverse effect of salinity on plant growth and development may be effectively reduced by application of salicylic acid. Plectranthus ciliatus is an attractive bed plant with ornamental leaves, recommended for growing in containers, hanging baskets, or sunny borders. The aim of this study was to investigate the response of $P$. ciliatus to salicylic acid and calcium chloride. The plants were grown in pots in a glasshouse and were sprayed with solution of $0.5 \mathrm{mM}$ salicylic acid and watered with $200 \mathrm{mM}$ calcium chloride. The application of salicylic acid resulted in an increased weight of the aboveground parts, higher stomatal conductance and leaf greenness index and enhanced leaf content of nitrogen, potassium, iron and zinc. Salinity-exposed plants were characterized by reduced weight, stomatal conductance and leaf greenness index. Salt stress caused also a drop in leaf content of nitrogen, potassium and iron, and an increase in calcium, sodium, chlorine, copper and manganese concentration. Salicylic acid seemed to relieve salinity-mediated plant stress.
\end{abstract}

Keywords: Plectranthus ciliatus, ion concentration, purple-leaved plectranthus, salinity stress.

\section{INTRODUCTION}

There is an ongoing search for ornamental plant species that can be successfully grown in urban landscapes areas where soil salinity is high [Villarino and Mattson, 2011; Niu et al., 2012; Breś et al., 2014]. High salinity of the soil along transportation routes, resulting from using salt for deicing streets in the winter, is a considerable threat to plants [Jull, 2009]. Salinity inhibits plant growth and development, mainly by disturbing nutrient absorption, inducing osmotic stress and due to direct ion toxicity [Greenway and Munns, 1980]. Another adverse factor limiting the use of green areas is their alkalization, resulting from dust deposition and accumulation of construction debris that introduce large quantities of calcium compounds into the soil [Breś, 2008]. Plants exhibit different tolerance to salinity depending on their adaptation to specific habitat conditions [Niu and Rodriguez, 2006; Niu and Cabrera, 2010].
Salicylic acid (SA) is a phenolic compound and a natural growth regulator in vascular plants [Larque-Saavedra and Martin-Mex, 2007; RivasSan Vicente and Plasencia, 2011]. It affects many physiological and metabolic processes [Jayakannan et al., 2015]. It also stimulates photosynthesis, transpiration, and ion uptake and transportation [Sahu, 2013]. Numerous studies have shown that exogenous salicylic acid induces plant resistance to abiotic stresses such as salinity, drought, heavy metals, too low or too high temperature or UV radiation [Yildirim et al., 2008; Li et al., 2014; Belkadhi et al., 2015; Khan et al., 2015; Taria et al., 2015]. Research literature does not provide any information regarding the use of salicylic acid in the cultivation of ornamental bedding plants, especially those exposed to salt stress.

Plectranthus L'Hér. (Lamiaceae) is a horticulturally important genus of about 300 species grown for foliage and flowers [Rice et al., 2011]. Some species are useful outdoors in large contain- 
ers, hanging baskets, or sunny borders. Plectranthus ciliatus E.Mey. ex Benth. is a native South Africa species [Potgieter et al., 1999]. It is a valuable ornamental plant with delicate white flowers and attractive leaves with green upper surface and purple lower surface [Bercu, 2013]. P. ciliatus can be grown in gardens and green areas. The species has also medicinal properties [Stavri and Gibbons 2007]. The effect of exogenous salicylic acid and salinity on the growth of $P$. ciliatus has not been examined so far.

The aim of this study was to compare changes in leaf greenness index and stomatal conductance, and leaf content of macro- and micronutrients in $P$. ciliatus exposed to salinity stress and treated with salicylic acid.

\section{MATERIALS AND METHODS}

The plant material included $10 \mathrm{~cm}$ rooted cuttings of Plectranthus ciliatus E.Mey. ex Benth. The plants were planted on 16 April 2014 into PCV pots with a capacity of $2.5 \mathrm{dm}^{3}$. Peat substrate $(\mathrm{pH}$ 6.0) was mixed with Azofoska fertilizer $\left(13.6 \% \mathrm{~N}, 6.4 \% \mathrm{P}_{2} \mathrm{O}_{5}, 19.1 \% \mathrm{~K}_{2} \mathrm{O}, 4.5 \%\right.$ $\mathrm{MgO}, 23.0 \% \mathrm{SO}_{3}, 0.045 \% \mathrm{~B}, 0.18 \% \mathrm{Cu}, 0.17 \%$ Fe, $0.27 \% \mathrm{Mn}, 0.04 \% \mathrm{Mo}$, and $0.045 \% \mathrm{Zn}$ ) at a dose of $2.5 \mathrm{~g} \cdot \mathrm{dm}^{-3}$ of the substrate. The pots were placed on tables in a greenhouse belonging to the West Pomeranian University of Technology in Szczecin $\left(53^{\circ} 25^{\prime} \mathrm{N}, 14^{\circ} 32^{\prime} \mathrm{E}\right)$.

The experimental variants were as follows:

- control - no treatment,

- spraying with salicylic acid solution,

- watering with $\mathrm{CaCl}_{2}$ solution,

- spraying with salicylic acid solution and watering with $\mathrm{CaCl}_{2}$ solution.

Each experimental variant included 16 plants, four plants per repetition. Salicylic acid (Sigma Aldrich, USA) was dissolved in small amount of $99.8 \%$ ethanol (Chempur, Poland). The plants were sprayed with $0.5 \mathrm{mM}$ SA four times, every five days starting from 10 May 2014. One plant was sprayed with about $10 \mathrm{~cm}^{3}$ of the solution. The solution was supplemented with Silwet Gold wetting agent (Momentive Performance Materiale, USA). The plants exposed to salinity stress were watered with $200 \mathrm{mM} \mathrm{CaCl}{ }_{2} \times 2 \mathrm{H}_{2} \mathrm{O}$ (Chempur, Poland) four times, every five days from 1 June 2014. Each time one plant in a pot was watered with $200 \mathrm{ml}$ of the salt solution. The plants were cultivated until 10 September 2014 under natural photoperiod. They were watered three times a week with tap water with EC 6.5. Temperature and relative humidity were recorded over the entire cultivation period by datalogger Testo-175-h2 (Table 1).

Physiological parameters were assessed in the first decade of September. Leaf greenness index (SPAD) was measured with an optical device Chlorophyll Meter SPAD 502 (Minolta, Japan). The measurements included five leaves located in the middle of a plant and three readings were taken per each leaf. Stomatal conductance was assessed with $\mathrm{SC} 1$ porometer (Dekagon Devices, USA). The measurements were performed only on sunny days between 10 a.m. and 12 p.m., and included five leaves per plant. Plant height, width and fresh weight of aboveground part were estimated on the last day of the cultivation. The collected leaves were dried, ground and sent to an accredited laboratory of the Chemical and Agricultural Station in Szczecin for determination of macro- and micronutrient content according to standard methods [Ostrowska et al., 1991]. Leaf chemical analyses were repeated three times for each experimental variant.

Statistical analysis of the results involved a univariate analysis of variance. Mean values were compared using Tukey test for a significance level $P=0.05$.

Table 1. The air temperature $\left({ }^{\circ} \mathrm{C}\right)$ and relative humidity $(\mathrm{RH} \%)$ during the experiment

\begin{tabular}{|c|c|c|c|c|c|c|c|}
\hline \multirow{2}{*}{\multicolumn{2}{|c|}{ Parameter }} & \multicolumn{6}{|c|}{ Month } \\
\hline & & \multirow{2}{*}{$\frac{\text { April }}{7.57}$} & \multirow{2}{*}{$\frac{\text { May }}{6.9}$} & \multirow{2}{*}{$\frac{\text { June }}{13.3}$} & \multirow{2}{*}{$\frac{\text { July }}{17.6}$} & \multirow{2}{*}{$\frac{\text { August }}{14.7}$} & \multirow{2}{*}{$\frac{\text { September }}{13.0}$} \\
\hline \multirow{3}{*}{${ }^{\circ} \mathrm{C}$} & Min. & & & & & & \\
\hline & Average & 15.1 & 18.9 & 19.7 & 24.1 & 19.6 & 18.3 \\
\hline & Max. & 23.8 & 25.0 & 27.3 & 32.5 & 25.6 & 25.9 \\
\hline \multirow{3}{*}{$\mathrm{RH} \%$} & Min. & 31.0 & 46.3 & 45.3 & 41.7 & 45.9 & 37.0 \\
\hline & Average & 62.0 & 76.9 & 70.6 & 69.4 & 78.5 & 80.4 \\
\hline & Max. & 86.9 & 98.5 & 98.5 & 99.3 & 97.7 & 99.7 \\
\hline
\end{tabular}




\section{RESULTS AND DISCUSSION}

The effects of SA and $\mathrm{CaCl}_{2}$ on the growth, leaf greenness index and stomatal conductance of $P$. ciliatus are presented in Figures 1-5. Apparently, SA and $\mathrm{CaCl}_{2}$ had no effect on P. ciliatus diameter (Figure 1) but both treatments affected plant height (Figure 2). The control plants were the highest, and the experimental ones were significantly shorter and of similar height (Figure 2). Growth inhibition of salt-treated plants has been widely reported by many authors [Niu et al., 2010,

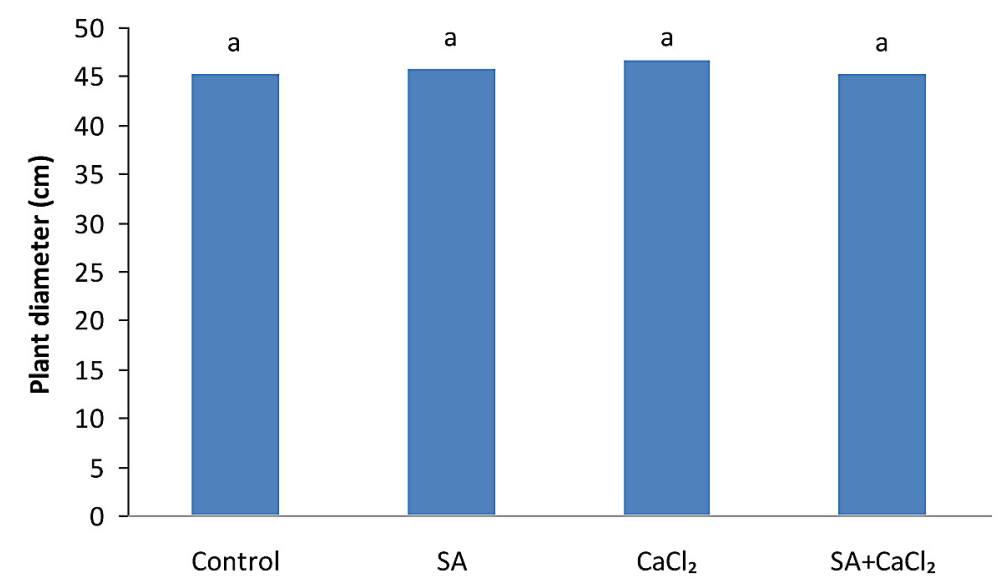

Figure 1. Effect of calcium chloride $\left(\mathrm{CaCl}_{2}\right)$ and salicylic acid (SA) on plant diameter of Plectranthus ciliatus. Means followed by the same letters are not significantly different, tested by Tukey's multiple comparison at $P=0.05$

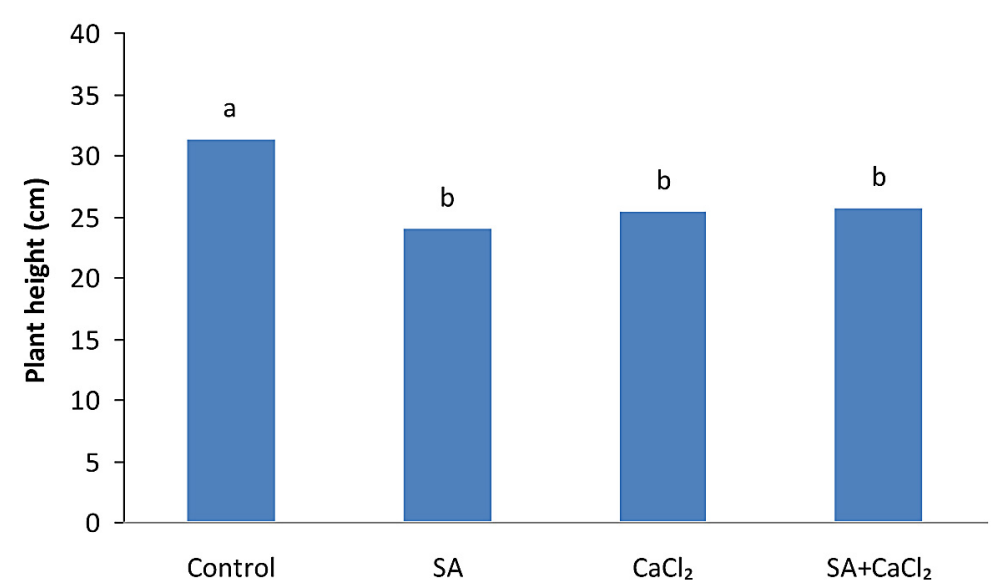

Figure 2. Effect of calcium chloride $\left(\mathrm{CaCl}_{2}\right)$ and salicylic acid (SA) on plant height of Plectranthus ciliatus. Means followed by the same letters are not significantly different, tested by Tukey's multiple comparison at $P=0.05$

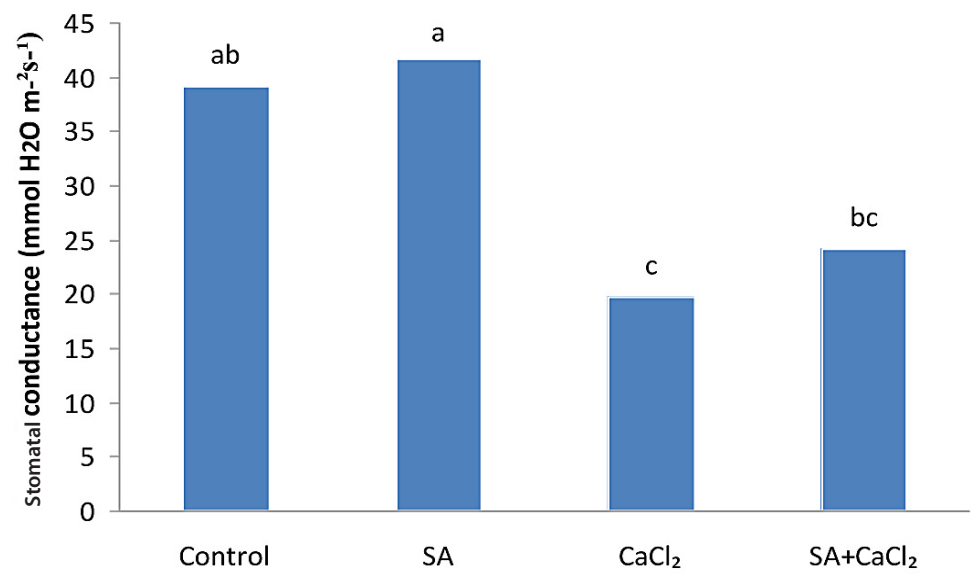

Figure 3. Effect of calcium chloride $\left(\mathrm{CaCl}_{2}\right)$ and salicylic acid (SA) on stomatal conductance of Plectranthus ciliatus. Means followed by the same letters are not significantly different, tested by Tukey's multiple comparison at $P=0.05$ 
Gao et al., 2012, Cai et al., 2014]. Plants treated with salicylic acid are usually higher [Gunes et al., 2007], but in some species SA treatment may restrict plant growth, especially when used at higher concentrations [Kovácik et al., 2009; Jayakannan et al., 2015].

The study investigated changes in stomatal conductance to figure out plant response to the growth stimulator and salt stress (Figure 3). The highest stomatal conductance was measured in the plants sprayed with $\mathrm{SA}\left(41.7 \mathrm{mmol} \mathrm{H}_{2} \mathrm{O} \mathrm{m}{ }^{-2}\right.$ $\mathrm{s}^{-1}$ ), thus indicating a stimulating effect of this compound on the intensity of photosynthesis. In the plants treated with $\mathrm{SA}+\mathrm{CaCl}_{2}$, stomatal conductance was by $4.5 \mathrm{mmol} \mathrm{H}_{2} \mathrm{O} \mathrm{m}^{-2} \mathrm{~s}^{-1}$ higher than in those treated with $\mathrm{CaCl}_{2}$ alone. The lowest stomatal conductance $\left(19.7 \mathrm{mmol} \mathrm{H}_{2} \mathrm{O} \mathrm{m}^{-2} \mathrm{~s}^{-1}\right)$ was read in the plants treated with $\mathrm{CaCl}_{2}$ alone (Figure $3)$. Our results confirm the reports of other au- thors on adverse effects of salinity on water management in plant cells and tissues [Bãnón et al., 2011]. Stomata are primary elements controlling leaf surface conductance and they regulate both water loss and $\mathrm{CO}_{2}$ assimilation during photosynthesis. Therefore, stomatal conductance is an important parameter of plant water status and it provides important information on plant growth and adaptation to variable environmental conditions [Arve et al., 2011].

The plants treated with salicylic acid were found to have the highest greenness index (Figure 4). A positive effect of SA on leaf chlorophyll content has also been shown by Li et al. [2014] in soybean seedlings. The lowest greenness index was noticed in the plants exposed to salinity stress (Figure 4). This finding was consistent with the data reported by Freitas et al. [2014], who described a drop in the greenness index in

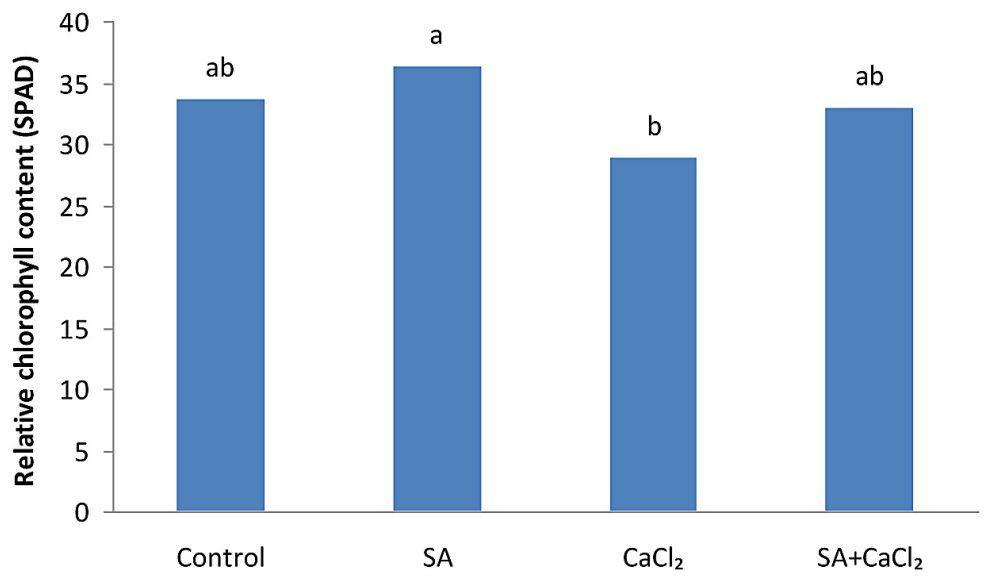

Figure 4. Effect of calcium chloride $\left(\mathrm{CaCl}_{2}\right)$ and salicylic acid (SA) on relative chlorophyll content of Plectranthus ciliatus. Means followed by the same letters are not significantly different, tested by Tukey's multiple comparison at $P=0.05$

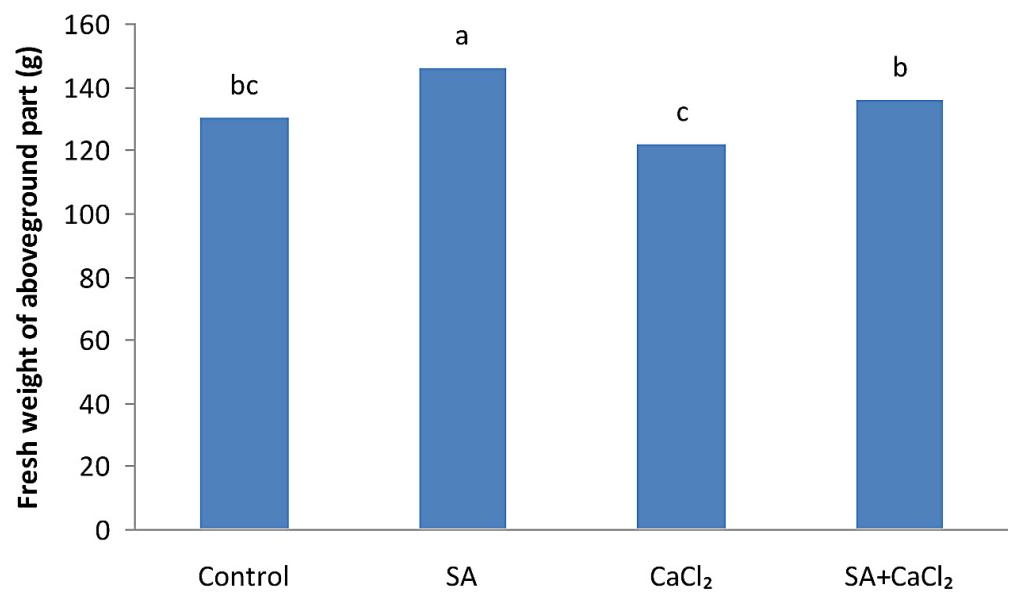

Figure 5. Effect of calcium chloride $\left(\mathrm{CaCl}_{2}\right)$ and salicylic acid (SA) on fresh weight of aboveground part of Plectranthus ciliatus. Means followed by the same letters are not significantly different, tested by Tukey's multiple comparison at $P=0.05$ 
Plectranthus amboinicus, Plectranthus barbatus and Plectranthus grandis watered with water with EC $0.7-5.5 \mathrm{dS} \mathrm{m}^{-1}$. They also reported P. amboinicus as a species most sensitive to salinity. Spraying $\mathrm{CaCl}_{2}$-treated plants with SA increased the greenness index that was by four SPAD units greater than in the plants treated with $\mathrm{CaCl}_{2}$ alone (Figure 4). Salt stress is known to inhibit nitrogen assimilation and disrupt protein metabolism [Starck 2005]. Chlorophyll synthesis is disturbed, which causes yellowing of leaves and tissue necrosis manifested by necrotic spots [Niu and Cabrera, 2010].

The plants treated with salicylic acid had the highest fresh weight of the aboveground part (Figure 5). Increased biomass resulting from SA treatment was also reported in Plectranthus tenuiflorus [Jalal et al., 2012]. The lowest fresh weight of the aboveground part was found in $P$. ciliatus watered with $\mathrm{CaCl}_{2}$ (Figure 5). A significant decrease in the weight of plants exposed to salinity stress was also observed in other three Plectranthus species, i.e. P. amboinicus, P. barbatus, and P. grandis [Freitas et al., 2014]. Fresh weight of the plants treated with $\mathrm{SA}+\mathrm{CaCl}_{2}$ was by $14 \mathrm{~g}$ greater than of those treated with $\mathrm{CaCl}_{2}$ alone (Figure 5). This seems to confirm previous reports on protective role of SA in plants exposed to salt stress [Manaa et al., 2014].

Date in Table 2 show the content of macronutrients in the leaves of P. ciliatus treated with salicylic acid and sodium chloride. Laboratory analyses revealed the highest content of nitrogen in the leaves sprayed with SA. Nitrogen is a macronutrient strongly affecting plant growth and yield and this is probably why plants treated with SA produced the highest biomass. Salicylic acid spraying resulted also in a significant increase in leaf potassium concentration. These findings were consistent with those of Amir et al. [2014] and Mirdad [2014], who reported enhanced content of nitrogen and potassium in SA-treated grapevine and broccoli.

The lowest content of $\mathrm{N}$ and $\mathrm{K}$ was found in the plants watered with $\mathrm{CaCl}_{2}$ (Table 2). These re- sults confirmed the findings of Freitas et al. [2014], who described reduced potassium concentration in the leaves of $P$. amboinicus, $P$. barbatus and $P$. grandis exposed to salt stress. Literature reports indicate that excessive concentration of ions, especially $\mathrm{Na}^{+}$and $\mathrm{Cl}^{-}$may limit the uptake of other ions, particularly $\mathrm{K}^{+}$and $\mathrm{Ca}^{2+}$ [Marschner, 1995]. Potassium is an essential ion determining cellular osmotic potential and stomata functioning [Oosterhuis et al., 2014]. In this study, the salttreated plants had low stomatal conductance that might be due to reduced potassium supply.

Sodium leaf content was higher in salt and salt + SA treated plants, as compared with control plants and those sprayed with SA alone (Table 2). The plants watered with $\mathrm{CaCl}_{2}$ and those treated with $\mathrm{CaCl}_{2}+\mathrm{SA}$ contained over six times more chlorine than the controls and the plants sprayed with SA alone. The highest calcium concentration was found in the plants watered with $\mathrm{CaCl}_{2}$, and the lowest in the control plants. Increased content of calcium and chlorine in the plants exposed to salt stress probably resulted from using $\mathrm{CaCl}_{2}$ solution.

No effects of salt or SA on the leaf concentration of phosphorus or magnesium were detected (Table 2), and their content ranged from 0.20 to $0.32 \% \mathrm{DW}(\mathrm{P})$ and from 0.70 to $0.77 \% \mathrm{DW}(\mathrm{Mg})$.

The data recorded in Table 3 present the effects of SA and $\mathrm{CaCl}_{2}$ on micronutrient concentration in the leaves of $P$. ciliatus. Its leaves were characterized by relatively high concentration of iron, as compared with other micronutrients, which is a common situation in plants. The highest iron content was found in SA-treated plants. Increased $\mathrm{Fe}$ concentration resulting from SA application was also reported in Arachis hypogaea [Kong et al., 2014]. The lowest Fe level was detected in the leaves of plants watered with $\mathrm{CaCl}_{2}$. These results confirmed the findings of Bhatt et al. [2008], who reported a significant decrease in $\mathrm{Fe}$ in the leaves of salt-treated Ziziphus mauritia$n a$. Iron is located mainly in chloroplasts, where

Table 2. Effect of salicylic acid (SA) and calcium chloride $\left(\mathrm{CaCl}_{2}\right)$ on the concentrations (\% dry weight) of macronutrients in the leaves of Plectranthus ciliatus. Means $(\mathrm{n}=3)$ within each column followed by the same letter are not significantly different, tested by Tukey's multiple comparison at $P=0.05$

\begin{tabular}{|c|c|c|c|c|c|c|c|}
\hline Treatments & $\mathrm{N}$ & $\mathrm{P}$ & $\mathrm{K}$ & $\mathrm{Ca}$ & $\mathrm{Mg}$ & $\mathrm{Na}$ & $\mathrm{Cl}$ \\
\hline Control & $0.61^{\mathrm{ab}}$ & $0.27^{\mathrm{a}}$ & $1.00^{\mathrm{ab}}$ & $1.57^{\mathrm{c}}$ & $0.77^{\mathrm{a}}$ & $0.24^{\mathrm{b}}$ & $0.64^{\mathrm{b}}$ \\
\hline $\mathrm{SA}$ & $0.85^{\mathrm{a}}$ & $0.20^{\mathrm{a}}$ & $1.41^{\mathrm{a}}$ & $2.69^{\mathrm{b}}$ & $0.70^{\mathrm{a}}$ & $0.27^{\mathrm{b}}$ & $0.59^{\mathrm{b}}$ \\
\hline $\mathrm{CaCl}_{2}$ & $0.57^{\mathrm{b}}$ & $0.31^{\mathrm{a}}$ & $0.86^{\mathrm{b}}$ & $4.65^{\mathrm{a}}$ & $0.75^{\mathrm{a}}$ & $0.31^{\mathrm{a}}$ & $4.19^{\mathrm{a}}$ \\
\hline $\mathrm{CaCl}_{2}+\mathrm{SA}$ & $0.65^{\mathrm{ab}}$ & $0.32^{\mathrm{a}}$ & $0.99^{\mathrm{ab}}$ & $3.97^{\mathrm{ab}}$ & $0.74^{\mathrm{a}}$ & $0.31^{\mathrm{a}}$ & $4.05^{\mathrm{a}}$ \\
\hline
\end{tabular}


Table 3. Effect of salicylic acid (SA) and calcium chloride $\left(\mathrm{CaCl}_{2}\right)$ on the concentrations micronutrients $(\mathrm{mg} / \mathrm{kg}$ dry weight) in the leaves of Plectranthus ciliatus. Means $(\mathrm{n}=3)$ within each column followed by the same letter are not significantly different, tested by Tukey's multiple comparison at $P=0.05$

\begin{tabular}{|c|c|c|c|c|c|}
\hline Treatments & $\mathrm{Fe}$ & $\mathrm{Mn}$ & $\mathrm{Cu}$ & $\mathrm{B}$ & $\mathrm{Zn}$ \\
\hline Control & $902^{\mathrm{b}}$ & $253^{\mathrm{b}}$ & $5.51^{\mathrm{b}}$ & $34.6^{\mathrm{b}}$ & $104^{\mathrm{b}}$ \\
\hline $\mathrm{SA}$ & $1125^{\mathrm{a}}$ & $223^{\mathrm{b}}$ & $5.31^{\mathrm{b}}$ & $24.0^{\mathrm{c}}$ & $119^{\mathrm{a}}$ \\
\hline $\mathrm{CaCl}_{2}$ & $621^{\mathrm{d}}$ & $357^{\mathrm{a}}$ & $7.14^{\mathrm{a}}$ & $26.4^{\mathrm{c}}$ & $110^{\mathrm{ab}}$ \\
\hline $\mathrm{CaCl}_{2}+\mathrm{SA}$ & $866^{\mathrm{c}}$ & $334^{\mathrm{a}}$ & $8.21^{\mathrm{a}}$ & $45.1^{\mathrm{a}}$ & $117^{\mathrm{a}}$ \\
\hline
\end{tabular}

it acts as a stimulator of synthesis of chlorophyll and some other proteins [Briat et al., 2015]. Low greenness index observed in $P$. ciliatus plants may be correlated with low leaf iron content.

Manganese concentration was significantly higher in the plants treated with $\mathrm{CaCl}_{2}$ and $\mathrm{SA}+$ $\mathrm{CaCl}_{2}$ (Table 3 ). Increased $\mathrm{Mn}$ leaf content was also reported in salt-treated Ziziphus mauritiana [Bhatt et al., 2008]. Manganese activates many enzymes and it is involved in the release of $\mathrm{O}_{2}$ during photosynthesis [Marschner, 1995]. Elevated concentration of $\mathrm{Mn}$ in $P$. ciliatus plants watered with $\mathrm{CaCl}_{2}$ might indicate their tolerance to salinity stress.

Plant tissues require maintaining a specific ratio of iron and manganese (Fe/Mn). In our study, mean Fe/Mn ratio was 2.2 and it was lower than that reported for Lamiaceae family (Fe/Mn above 4) encompassing P. ciliatus. However, Fe/Mn ratio may vary from below 1.0 to over 4.0 and it depends on taxonomic features [Starck, 2005].

Leaves of the plants treated with $\mathrm{CaCl}_{2}$ and $\mathrm{SA}+\mathrm{CaCl}_{2}$ contained significantly more copper as compared with the control plants and those sprayed with SA alone (Table 3). Copper plays an important role in photosynthesis and respiration, in the metabolism of sugars and nitrogen compounds, and in cell wall lignifications [Starck, 2005]. Increased copper content in plants grown under salt stress may be due to a participation of this micronutrient in the process of adaptation to these conditions [Waraich et al., 2011].

The highest boron content was found in salt + SA treated plants (Table 3). The lowest boron content was measured in plants treated with $\mathrm{CaCl}_{2}$ or SA. Boron is involved in the formation of cell wall structures, plant growth, and indirectly in carbohydrate metabolism [Starck, 2005].

Higher concentration of zinc was detected in the plants sprayed with SA and sprayed with $\mathrm{SA}$ and watered with $\mathrm{CaCl}_{2}$ (Table 3). The lowest zinc content was measured in the control plants. An increase in $\mathrm{Zn}$ concentration follow- ing SA application was also reported in peppers [El-Yazied, 2011] and Arachis hypogaea [Kong et al., 2014]. Zinc plays different roles in plant vital processes, it activates the enzymes involved in sugar and protein metabolism, stabilizes protein structure and controls gene expression [Sadeghzadeh and Rengel, 2011].

\section{CONCLUSIONS}

1. Salicylic acid treatment increased plants' fresh weight, stomatal conductance, leaf greenness index and leaf content of nitrogen, potassium and iron.

2. Salinity stress reduced plant weight, stomatal conductance and leaf greenness index. Moreover, the leaves of salt-exposed plants contained less nitrogen, potassium, and iron and more calcium, sodium, chlorine, copper, and manganese.

3. Salicylic acid relieved the adverse effects of $\mathrm{CaCl}_{2}$, as demonstrated by increased plant fresh weight, stomatal conductance and leaf greenness index compared to plants treated with $\mathrm{CaCl}_{2}$ alone.

\section{REFERENCES}

1. Amir J., Eshghi S., Tafazoli E., Kholdebarin B., Abbaspour N. 2014. Ameliorative effects of salicylic acid on mineral concentrations in roots and leaves of two grapevine (Vitis vinifera L.) cultivars under salt stress. VITIS - J. Grapevine Res., 53 (4), 181-188.

2. Arve L.E., Torre S., Olsen J.E., Tanino K.K. 2011. Stomatal responses to drought stress and air humidity. In: Abiotic stress in plants - mechanisms and adaptations, A. Shanker, B. Venkateswarlu (eds.), InTech, Rijeka, Croatia.

3. Bãnón, S., Miralles, J., Ochoa, J., Franco, J.A., Sánchez-Blanco, M.J. 2011. Effects of diluted and undiluted treated wastewater on the growth, physi- 
ological aspects and visual quality of potted lantana and polygala plants. Sci. Hort., 129, 869-876.

4. Belkadhi A., De Haro A., Obregon S., Chaibi W., Djebali W. 2015. Exogenous salicylic acid protects phospholipids against cadmium stress in flax ( $\mathrm{Li}$ num usitatissimum L.) Ecotoxicol. Environ. Saf., 120, 102-109.

5. Bercu R. 2013. Comparative anatomy of two Lamiaceae species leaves with ornamental value. Ann. Rom. Soc. Cell Biol., 18 (1), 232-238.

6. Bhatt M.J., Patel A.D., Bhatti P.M., Pandey A.N. 2008. Effect of soil salinity on growth, water status and nutrient accumulation in seedlings of Ziziphus mauritiana (Rhamnaceae). Fruit. Ornam. Plant Res., 16, 383-401.

7. Breś W. 2008. Czynniki antropopresji powodujące zamieranie drzew w krajobrazie miejskim. Nauka Przyr. Technol. 2, 4, p. 31.

8. Breś W., Kupska A., Trelka T. 2014. Response of scarlet sage and common sunflower plants to salinity caused by sodium salts. Folia Pomer. Univ. Technol. Stetin., Agric., Aliment., Pisc., Zootech., 315(32), 5-14.

9. Briat J.-F., Dubos C., Gaymard F. 2015. Iron nutrition, biomass production, and plant product quality. Trends Plant Sci., 20 (1), 33-40.

10. Cai X., Niu G., Starman T., Hall C. 2014. Response of six garden roses (Rosa $\times$ hybrida L.) to salt stress. Sci. Hortic., 168, 27-32.

11. El-Yazied A.A. 2011. Effect of foliar application of salicylic acid and chelated zinc on growth and productivity of sweet pepper (Capsicum annuum L.) under autumn planting. Res. J. Agric. Biol. Sci. 7(6), 423-433.

12. Freitas M.A.C., Amorim A.V., Bezerra A.M.E., Pereira M.S., Bessa M.C., Nogueira Filho F.P., Lacerda C.F. 2014. Growth and salinity tolerance in three medicinal species of the genus Plectranthus exposed to different levels of solar radiation. Rev. Bras. Plantas Med., 16 (4), 839-849.

13. Gao J., Gu M., Niu G., Chen Y. 2012. Effects of salinity on three Pennisetum cultivars. J. Food Agric. Environ., 10 (3-4), 1005-1007.

14. Greenway H., Munns R. 1980. Mechanisms of salt tolerance in non-halophytes. Annu. Rev. Plant Physiol., 31, 149-190.

15. Gunes A, Inal A, Alpaslan M, Eraslan F, Guneri Bagci E, Cicek N. 2007. Salicylic acid induded changes on some physiological parameters symptomatic for oxidative stress and mineral nutrition in maize (Zea mays L.) grown under salinity. J. Plant Physiol., 164(728), 736.

16. Jalal R.S., Bafeel S.O., Moftah A.E. 2012. Effect of salicylic acid on growth, photosynthetic pigments and essential oil components of Shara (Plec- tranthus tenuiflorus) plants grown under drought stress conditions. Int. Res. J. Agric. Sci. Soil Sci., 2(6), 252-260.

17. Jayakannan M., Bose J., Babourina O., Rengel Z., Shabala S. 2015. Salicylic acid in plant salinity stress signalling and tolerance. Plant Growth Regul., 76(1), 25-40.

18. Jull L.G. 2009. Winter salt injury and salt tolerant landscape plants. Division of Cooperative Extension, University of Wisconsin, A3877, 1-12.

19. Khan M.I.R., Fatma M., Per T.S., Anjum N.A., Khan N.A. 2015. Salicylic acid-induced abiotic stress tolerance and underlying mechanisms in plants. Front. Plant Sci., 6, 462.

20. Kong J., Dong Y., Xu L., Liu S., Bai X. 2014. Effects of foliar application of salicylic acid and nitric oxide in alleviating iron deficiency induced chlorosis of Arachis hypogaea L. Bot. Stud., 55, 9.

21. Kovácik J, Grúz J, Backor M, Strnad M, Repcák M. 2009. Salicylic acid-induced changes to growth and phenolic metabolism in Matricaria chamomilla plants. Plant Cell Rep., 28, 135-143.

22. Larque-Saavedra A., Martin-Mex R. 2007. Effects of salicylic acid on the bioproductivity of plants. In: S. Hayat, A. Ahmad (Eds.) Salicylic acid: A plant hormone. Springer Publishers. Dordrecht. The Netherlands, 15-23.

23. Li T., Hu Y., Du X., Tang H., Shen C., Wu J. 2014. Salicylic acid alleviates the adverse effects of salt stress in Torreya grandis cv. Merrillii seedlings by activating photosynthesis and enhancing antioxidant systems. PLoS ONE, 9 (10), no. e109492.

24. Li X.M., Ma L.J., Bu N., Li Y.Y., Zhang L.H. 2014. Effects of salicylic acid pre-treatment on cadmium and/or UV-B stress in soybean seedlings. Biol. Plantarum, 58 (1), 195-199.

25. Manaa A., Gharbi E., Mimouni H., Wasti S., AschiSmiti S., Lutts S., Ben Ahmed H. 2014. Simultaneous application of salicylic acid and calcium improves salt tolerance in two contrasting tomato (Solanum lycopersicum) cultivars. S. Afr. J. Bot., 95, 32-39.

26. Marschner H. 1995. Mineral nutrition of higher plants (2nd ed.). Academic Press, New York

27. Mirdad Z.M. 2014. Effect of K+ and salicylic acid on broccoli (Brassica oleraceae var. italica) plants grown under saline water irrigation. J. Agric. Sci. 6 (10), 57-66.

28. Niu G., Cabrera R.I. 2010. Growth and physiological responses of landscape plants to saline water irrigation: A review. HortScience, 45(11), 1605-1609.

29. Niu G., Rodriguez D.S. 2006. Relative salt tolerance of selected herbaceous perennials and groundcovers. Sci. Hortic., 110(4), 352-358.

30. Niu G., Rodriguez D.S., McKenney C. 2012. Response of selected wildflower species to saline wa- 
ter irrigation. HortScience, 47(9), 1351-1355.

31. Niu G., Rodriguez D.S., Starman T. 2010. Response of bedding plants to saline water irrigation. HortScience 45(4), 628-636.

32. Oosterhuis D.M., Loka D.A., Kawakami E.M., Pettigrew W.T. 2014. The physiology of potassium in crop production. Adv. Agron., 126, 203-233.

33. Ostrowska A., Gawliński S., Szczubiałka Z. 1991. Metody analizy i oceny właściwości gleb i roślin. Instytut Ochrony Środowiska. Warszawa.

34. Potgieter C.J., Edwards T.J., Miller R.M., Van Staden J. 1999. Pollination of seven Plectranthus spp. (Lamiaceae) in southern Natal, South Africa. Plant Syst. Evol., 218 (1-2), 99-112.

35. Rice L.J., Brits G.J., Potgieter C.J., Van Staden J. 2011. Plectranthus: A plant for the future? S. Afr. J. Bot., 77 (4), 947-959.

36. Rivas-San Vicente M., Plasencia J. 2011. Salicylic acid beyond defence: its role in plant growth and development. J. Exp. Bot., 62, 3321-3338.

37. Sadeghzadeh B., Rengel Z. 2011. Zinc in soils and crop nutrition. In: M.J. Hawkesford, P. Barraclough (Eds.) The molecular and physiological basis of nutrient use efficiency in crops, Wiley-Blackwel,
Sussex, UK, 335-375.

38. Sahu G.K. 2013. Salicylic acid: Role in plant physiology and stress tolerance. In: G.R. Rout, A.B. Das (Eds.) Molecular stress physiology of plants. Springer, India, 217-239.

39. Starck Z. 2005. Gospodarka mineralna roślin. In: J. Koncewicz, S. Lewak (Eds.) Fizjologia roślin. PWN Warszwa, 232-239.

40. Stavri M., Gibbons S. 2007. Antibacterial constituents from Plectranthus ciliatus. Planta Med., 73,158 .

41. Taria S., Joshi N., Samal S.K., Mishra B.K. 2015. Salicylic acid and high temperature stress. Ann. Biol., 31(1), 18-23.

42. Villarino G.H., Mattson N.S. 2011. Assessing tolerance to sodium chloride salinity in fourteen floriculture species. HortTechnology, 21(5), 539-545.

43. Waraich E.A., Ahmad R., Ashraf M.Y. 2011. Role of mineral nutrition in alleviation of drought stress in plants. Aust. J. Crop Sci., 5 (6), 764-777.

44. Yildirim E., Turan M., Guvenc I. 2008. Effect of foliar salicylic acid applications on growth, chlorophyll, and mineral content of cucumber grown under salt stress. J. Plant Nutr., 31 (3), 593-612. 